Article

\title{
Farmers' Perception and Drivers of Membership in Rice Production Community Enterprises: Evidence from the Central Region, Thailand
}

\author{
Wachira Petcho ${ }^{1}$, Sylvia Szabo ${ }^{1,2, *}$, Kyoko Kusakabe ${ }^{1}$ () and Vimolwan Yukongdi ${ }^{3}$ \\ 1 Department of Development and Sustainability, School of Environment, Resources and Development, \\ Asian Institute of Technology, Klong Luang, Pathum Thani 12120, Thailand; st118391@ait.asia (W.P.); \\ kyokok@ait.asia (K.K.) \\ 2 Division of Social Statistics and Demography, University of Southampton, University Road Southampton, \\ Southampton SO17 1BJ, UK \\ 3 School of Management, Asian Institute of Technology, Klong Luang, Pathum Tthani 12120, Thailand; \\ vyukongdi@ait.ac.th \\ * Correspondence: sylviaszabo@ait.asia
}

Received: 19 September 2019; Accepted: 29 September 2019; Published: 1 October 2019

\begin{abstract}
In rapidly developing economies such as Thailand, farmers face multiple challenges preventing them from improving their livelihoods, and are therefore reverting to collective action as a means to overcome those obstacles. Community enterprises (CEs) have recently emerged as a new form of such collective action, yet there is limited evidence regarding farmers' perception of rice production CEs (RPCEs) and the specific factors influencing their decision to join. In order to fill this gap, primary data were collected through questionnaires administered to 406 farmers in six districts in Uthai Thani province in the central region of Thailand. A weighted average index (WAI) was employed to assess the farmers' perception of RPCEs' role, and a binary logit regression model was used to investigate the determinants of perception and membership in RPCEs. The results revealed that both members and non-members perceived RPCEs as a saving source but not a credit provider. Compared to non-members, members put more emphasis on the product competition with rivals. Decision to join was associated with small landholdings, diversity of rice varieties cultivated, participation in networks, membership of economic groups, access to extension services, access to credit, and proximity to the market. The results suggest that production-oriented and marketing-oriented policies should be promoted in order to encourage farmers to cultivate organic rice and rice for the niche market to supply to RPCEs in order to generate greater group income.
\end{abstract}

Keywords: community enterprise; rice production; perception; decision to join; membership; Thailand

\section{Introduction}

Improving agricultural productivity and commercialization of agricultural products among smallholder farmers is widely perceived as a key approach for rural development, poverty alleviation, and food security. The main challenges include poor access to credit services [1], inadequate infrastructure and physical dispersion of smallholders [2], the high transaction costs of accessing input and output markets, technical incapability [3], and changing consumer preferences [4]. Collective action is often suggested as a tool to overcome those obstacles [5].

Collective action is defined as a group of people who collaborate in order to pursue members' shared interests [6]. It is the coordinated behavior of a group toward a common interest or purpose [7]. Collective action groups can be of many types such as labor-sharing groups or self-help groups, and perform a wide range of activities including agricultural production, management of natural 
resources, and technology dissemination. Moreover, collective action can involve more complex farmer associations, as well as cooperative societies engaged in marketing activities, input supply, and provision of specialized services.

Community enterprises (CEs) represent one type of collective action. CE refers to a group of individuals in a community that acts in pursuit of a common good [8]. It is formed as a result of a local community's entrepreneurial activities, employing their social resources, structures, and networks [9]. CEs are managed and governed by local citizens who aim to pursue a common purpose in a manner that is meant to yield sustainable individual and group benefits over a short and long period $[8,10]$. Local knowledge, culture, resources, and capacity to run CEs relies on people and the natural resources in their community areas. Local people use CEs as a means for enhancing their livelihoods by creating new sources of income, securing better access to their resources and consolidating their land claims [11].

CEs employ entrepreneurial means to solve their economic, social, cultural, and environmental issues. In many studies, entrepreneurship has been identified as a significant path towards sustainable products and services, and addresses many environmental and social concerns [12]. Recently, it has been considered as a solution for numerous environmental and social preoccupations [13-15]. Entrepreneurial knowledge and innovative abilities play a vital role in finding opportunities for sustainable development [14] and ensuring a more sustainable future. Hence, entrepreneurs are the engines of sustainable development [16].

Meanwhile, CEs are also similar to cooperatives in being member-owned and controlled trading organizations $[17,18]$. CEs are distinguished between community cooperatives, which have more membership control, and community non-profits, which are more about producing social benefits for the community [17]. An empirical study in India defined the meaning of CEs following the definition of cooperatives: the association of people in pursuit of common economic, social, and cultural goals through a jointly-owned and democratically-controlled enterprise [19]. CEs and cooperatives are interchangeable [18].

In Thailand, CEs were introduced after the financial crisis in 1997. Following the economic collapse, the government developed the concept of sufficiency economy and self-reliance, which were important parts of community thinking as strategies to survive the crisis and bypass this concept into government projects. CEs have been a grassroots economic development means for increasing the potential and roles of rural communities since then [20], and have become part of the community-based income generation program of the Thai government as an instrument for stimulating self-employment [21]. Local people contribute finance and local resources for production, and participate in production and sale activities [22]. According to a recent report by the Secretariat of Community Enterprise Promotion Board (SCEB) [23], the highest registered number of CEs in the crop production sector operate in the rice production community enterprise (RPCE). Rice plays a crucial role in the livelihoods of the Thai people and is an important cash crop for the country. One-fifth of the territory, or 70 million rai, is used for paddy farming [24]. Over two million farmers are paddy farmers, more than any other type of farmer. [25]. Furthermore, rice is the major export, with an average value of over US billion dollars per year. In 2012, it generated an export value of approximately $\$ 436.4$ million [26].

Previous studies on CEs indicate that most challenges they face are related to management aspects. These include lack of experience in organizational management, high costs of production, lack of working capital [27], weak information systems, poor product design [28], and lack of knowledge and skills on the part of the entrepreneur [29]. Regarding farmers' perception, some studies have shown that farmers' perception of CEs is mostly positive because they associate cooperatives with the possibility of obtaining assistance from their government representatives [30]. Farmers have indicated that the availability of loans, improvement of profit, and services provided by the cooperatives such as finance, training, and transportation influenced them to join [31]. Cooperative members improve their knowledge and skills through various training, and develop farming practices due to accessibility of farm inputs [32]. Nonetheless, few studies have thus far assessed farmers' perception of RPCEs or the factors influencing perception and the decision to join an RPCE. Such evidence is critical to inform 
policy, help paddy farmers to receive the advantages associated with membership of RPCEs, increase their chances to enhance paddy farming, and thus improve their livelihoods.

\section{CEs and RPCEs in Thailand}

CEs were introduced in Thailand after the 1997 economic crisis. CEs have been promoted as an income generation program through the provision of a training program and enlarged sources of funding. In 2005, the Royal Government of Thailand issued the "CEs Promotion Act" to support and build an enabling environment and encourage the formation of CEs. By helping small micro-businesses, CEs become legal entities, and the Act improved these enterprises' chances of receiving both recognition and various types of government support. In addition, the micro-finance sources of support for CE implementation come from many organizations, such as local administrative organizations, the Bank for Agriculture and Agricultural Co-operatives, non-governmental organizations, shared interests, and self-organization [33]. The CE program was one of the biggest public interventions implemented in the country [21].

CEs are also used to solve the limitation of cooperatives and private companies that prevents grassroots groups from acting as collective entrepreneurs [34]. With fewer regulations, seven or more villagers who aim to produce and market a product or service can register as CEs [35]. All existing groups, e.g., organically formed groups and top-down process groups, were encouraged to register to receive support from the government in accordance with the CE Act 2005. At the time of this research, there were more than 85,000 CEs with over 1.4 million members across Thailand [36]. CEs are divided into two types: goods and services. Goods cover 18 items, including crops (e.g., rice, cassava, etc.), livestock, fishery, and food processing, while services include such as community shops, and tourism. CEs became a foundation for the "one tambon (sub-district) one product" (OTOP) scheme in 2001; approximately $68 \%$ of OTOP producers are CEs, and $34 \%$ of CEs in the country are engaged in OTOP activities [37].

RPCEs were the highest registered crop production type [23]. Principally, CEs should be set up by grassroots groups to solve problems together at household and community level, but many have instead been formed by a top-down process. In 2005, the number of registered RPCEs was relatively high because they consisted of both the existing paddy farmer groups and newcomers (Figure 1) [38]. Between 2008 and 2009, the number of registered RPCEs declined and then picked up again around 2010. Since 2015, the government has promoted the Large Agricultural Plot Scheme (LAPS) policy [39]. This policy was aimed to increase rice production and enhance the competitiveness of small-scale rice farmers by encouraging them to establish neighboring agricultural land groups in order to share plans for cropping and marketing development. Many paddy farmers formed RPCEs to benefit from this project in the form of inputs, training, machines, and micro-finance. Some farmers left their old RPCEs and joined new RPCEs following this government project.

The current study considers seven RPCEs, four of which were initially formed as farmer groups with the objective to reduce production cost. The three others were initiated by government promotion. All RPCEs have a common membership size, ranging approximately from 35 to 68 members. RPCEs access the market though offering organic rice and rice for the niche market since commercial rice (conventional rice) is dominated by mills/middle. In the past, RPCEs were open to all individuals, but now several of them require farmers with a willingness to provide produces to the group. All RPCEs are managed by an elected chairperson and the board following the democratic principle of one person, one vote. Common share is the main payment of membership for all RPCEs; it averages $100 \mathrm{baht} / \mathrm{share}$ but can be up to 1,000 baht/share. Fee registration is paid for some RPCEs at an average of 100 baht. Although the type of activities within RPCEs may differ, they often include distributing inputs to members and stabilizing outputs by setting a minimum threshold. Regarding marketing, RPCEs collect dried and fresh rice from members and participate in post-harvest activities such as rice milling and packaging. They have customers in both local and urban markets. 


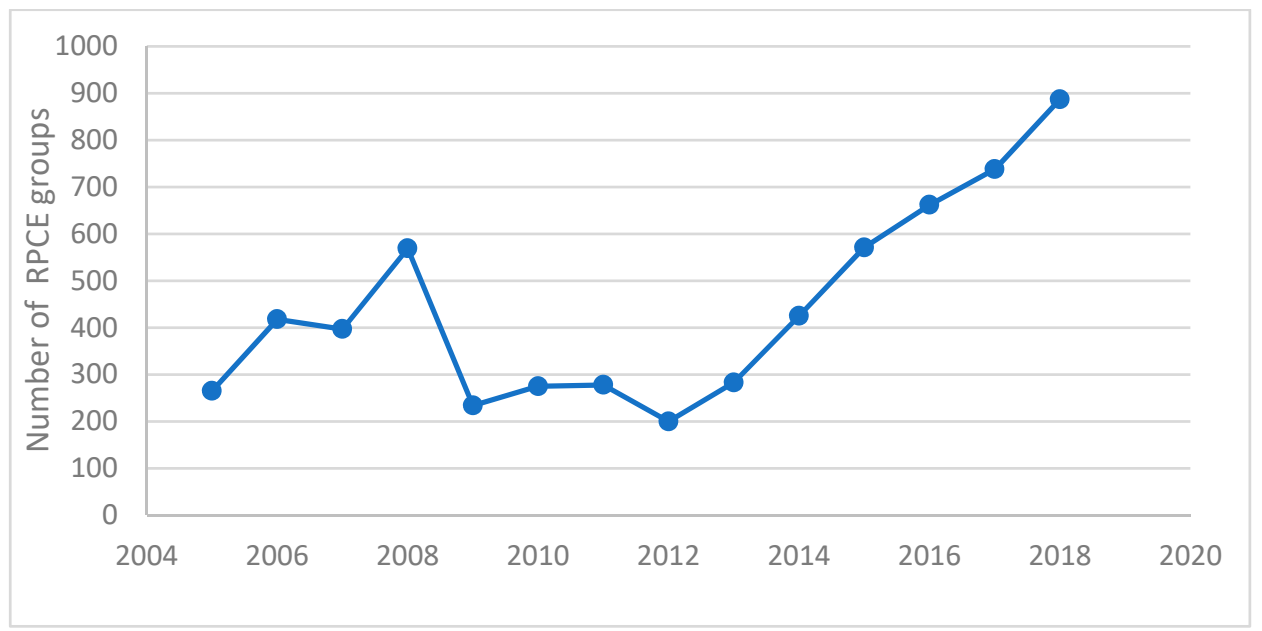

Figure 1. The number of registered RPCEs (rice production community enterprises) in Thailand from 2005-18. Data source: SCEB, 2019.

\section{Materials and Methods}

\subsection{Study Area}

Uthai Thani province was chosen purposely for the study. It is located in the central part of the country (Figure 2). The central region is Thailand's major location for commercial rice production. Farmers in this region normally grow at least two crops of rice per year due to the availability of the irrigation system and sufficient water. The share of farm income of households that depend on rice production in this region is about $27 \%$ (three-fifths of total household income), constituting the largest share in Thailand [40]. The total population of this province is 329,433 [41], and most people rely on agriculture for their livelihoods, in particular rice production. The total of agricultural land accounted for 260,217.44 ha, of which 103,421.76 ha was used for rice farming and the rest for field, orchard and perennial crops [41]. The field data were collected between February and April 2019.
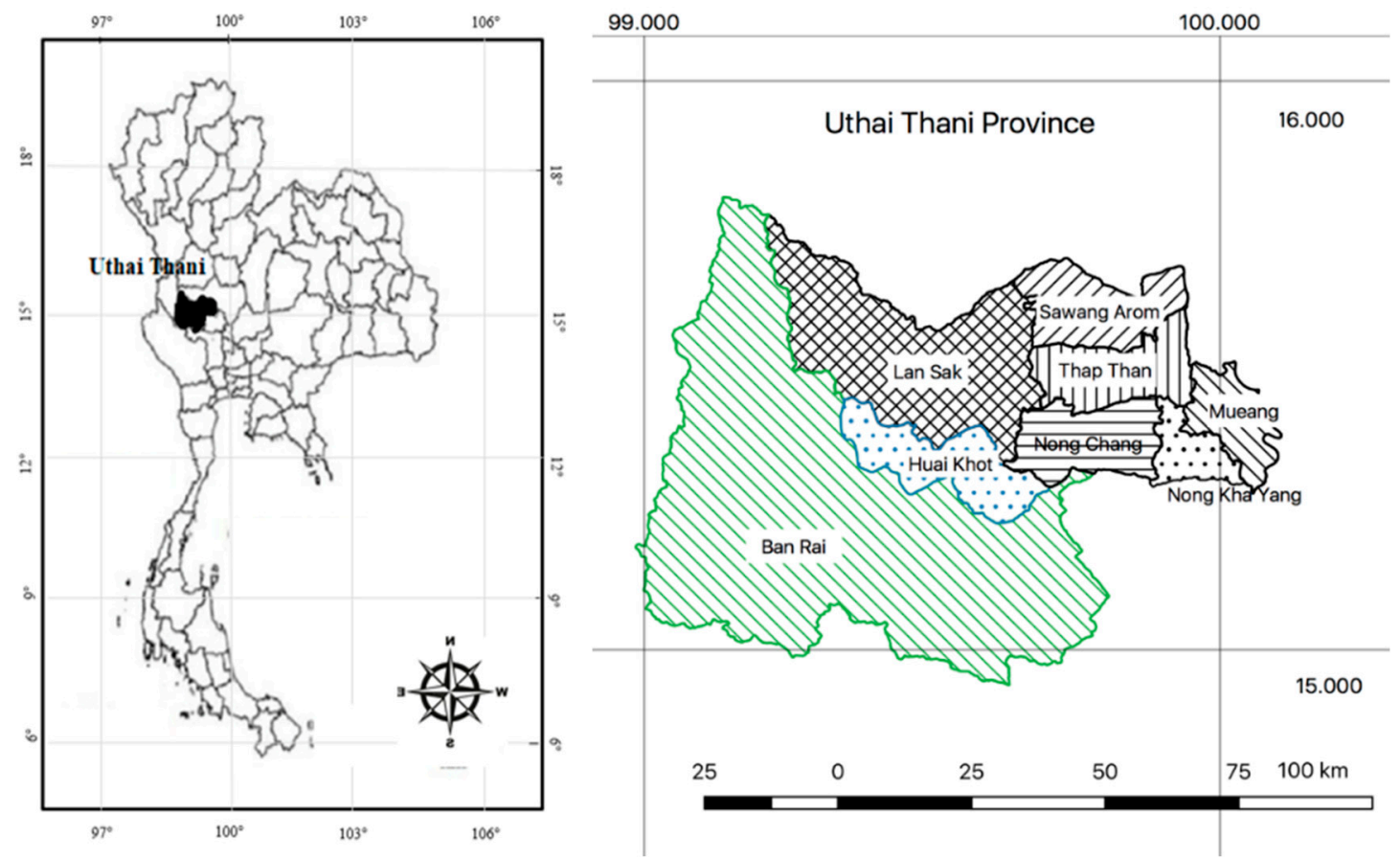

Figure 2. Map of Uthai Thani province (study area) 


\subsection{Sampling Methods, Population and Sample Size}

A multi-stage sampling procedure was used to select sample households for the empirical analysis. In the first stage, Uthai Thani province was purposely selected. In the second, six out of eight districts, namely Mueng, Thap Than, Sawang Arom, Lansak, Nongkhayang, and Nongchang were selected due to their similarity of in terms of agro-ecology. A total of seven RPCEs were purposely selected from Mueng, Thap Than, Lansak, Sawang Arom, Nongkhayang, and Nongchang districts. Subsequently, based on the complete list of households in each village served by each RPCE, a total of 406 representative households (178 members and 228 non-members) were randomly selected.

A household survey was conducted through a semi-structured questionnaire and face-to-face interviews for the primary data. Secondary data were collected from relevant sources, including the Ministry of Agriculture and Cooperatives, National Statistical Office, and District Administrative Office. Moreover, group discussions and chairperson/key person interviews were held, where participants were asked about the overall role of RPCEs, e.g., activities, management, problems and the benefits of RPCEs for their members and their community.

\subsection{Methods of Analysis}

The data analysis used quantitative and qualitative methods and was carried out with STATA version 15 . Chi-square and $t$-test were used to assess the associations between characteristics of the survey respondents (reported in Table 2). Furthermore, weighted average index, and regression modeling were applied to in this research (reported in Tables 3 and 4). To interpret the results of the logistic regression, we reported the marginal effects, which are interpreted as marginal changes of the dependent variables as a result of changes in the respective explanatory variables [42,43].

\subsubsection{Weighted Average Index (WAI)}

The weighted average index (WAI) was employed to assess the farmers' perceptions of RPCEs' role. The WAI formula is as follows [44]:

$$
\mathrm{WAI}=\sum \frac{S_{i} F_{i}}{N}
$$

where the WAI is $(0 \leq \mathrm{WAI} \leq 1), S_{i}$ denotes the scale value assigned based on the response, $F_{i}$ denotes the frequency of responses, and $N$ denotes the total number of responses. The level of perception was measured on a five-point scale with varying weights. The degree was weighted as 1 for "Very Strong" (VS), 0.75 for "Strong" (S), 0.5 for "Medium" (M), 0.25 for "Weak" (W), and 0 for "Very Weak" $(V W)$. Numerous studies have used this approach to examine farmers' perceptions and associated decision-making [45-47].

\subsubsection{Binary Logistic Regression Model}

The binary logistic regression model was applied to evaluate the relationship of the observed characteristics with perception and probability of membership. Logistic regression is often used in socio-economic and environmental research when the outcome variable is binary [48] and it has also been frequently applied when assessing the factors influencing farmers' motivations and decisions [49,50]. The probability of being a RPCEs member can be modeled as a function of selected independent variables. Two separate logit regressions were estimated to determine the factors influencing farmers' perception of RPCEs and the factors determining their decision about whether to be an RPCE member. The logit model formula is as follows [51]:

$$
P_{i}=F\left(Z_{i}\right)=F\left(\alpha+\beta X_{i}\right)=\frac{1}{1+e^{-Z_{i}}}=\frac{1}{1+e^{-\left(\alpha+\beta_{i}\right)}}
$$


where $e$ represents the base of natural logarithms, $P_{i}$ is the probability that an individual farmer has a positive perception of CEs and will make the decision to join an RPCE $(0=$ no, $1=$ yes $)$ given $X_{i}$, where $X_{i}$ is the set of explanatory variables that influence perception and the choice of membership of RPCEs, and $\beta$ the coefficients of the explanatory variables. Equation (3) can be restated as:

$$
\log _{e} \frac{P_{i}}{1-P_{i}}=Z_{i}=\alpha+\beta X_{i}
$$

We followed the standard stepwise regression procedure. Model selection was undertaken using the frequently applied statistical tests, such as log likelihood ratio tests and pseudo $R^{2}[3,52]$.

\subsection{Variables}

\subsubsection{Outcome Variable}

The outcome variables are perception and membership. Both are dichotomous variables. Perception measures household level in terms of their perception of RPCEs by providing the value 1 if a farmer has a positive perception of RPCEs, making them a treatment group member. Membership measures household level in terms of decision to join an RPCE. The variable takes the value 1 if a farm household has RPCE membership, making them a treatment group member. It takes the value 0 if a farm household does not have RPCE membership, making them a control group member [53-57].

\subsubsection{Explanatory Variables}

Previous studies have shown that farmers' perceptions and decisions to join different forms of cooperatives and agricultural groups are influenced by household level and individual socio-economic and demographic characteristics. The membership of cooperatives is positively associated with age [53,54], education level [54], farming experience [58,59], and family size [49].

Regarding asset endowment, previous studies have found that the size of landholding and ownership of livestock are associated with the likelihood of cooperative membership $[43,55,56]$. Rice farm size is the factor influencing farmers to join RPCEs. For example, farmers with larger farm sizes are more likely to belong to cooperatives in China [60]. Prior studies have shown that the degree of agro-commodity diversity is linked with the decision to join a cooperative [55]. Based on the existing literature and feedback from fieldwork, we therefore include a variable measuring the diversity of rice varieties cultivated.

Empirical studies have shown that individual social networks are involved in the adoption of technologies and other innovations among smallholder farmers [42], and access to a social network is probably an important variable in membership decisions [3]. Personal preferences for working in groups are reflected by membership of other groups [61], thus, membership of an economic group enhances household members' knowledge and generates ideas related to production and marketing. Extension service has an effect on farmers' decision to join an RPCE, reflecting the important role of government extension services in promoting and developing RPCEs. Credit enables farmers to overcome their financial constraints and adopt innovations; thus, it is likely that access to credit will be associated with organizational membership [50]. Distance to market can influence farmers to become members of RPCEs. For example, previous studies have found a relationship between the probability of cooperative membership and collection centers in Ethiopia [49] and India [62]. The variables and their measurement are described on the Table 1. 
Table 1. Description of variables and their measurement.

\begin{tabular}{|c|c|}
\hline Variables & Description \\
\hline \multicolumn{2}{|l|}{ Outcome variables } \\
\hline Membership status & $\begin{array}{l}\text { Membership status in a RPCEs (rice production community } \\
\text { enterprise) }(1=\text { member; } 0=\text { otherwise) }\end{array}$ \\
\hline Perception & If household had a positive perception on RPCEs $(1=$ yes; $0=$ no $)$ \\
\hline \multicolumn{2}{|l|}{ Explanatory Variables } \\
\hline Age & Age of household head (years) \\
\hline Education & $\begin{array}{l}\text { The education level of the household head ( } 1=\text { illiteracy; } \\
2=\text { primary; } 3 \text { = secondary; } 4=\text { bachelor degree and above) }\end{array}$ \\
\hline Family size & Number of family members \\
\hline Farm experience & Number of years since the household head started rice production \\
\hline Landholding & Total land size owned by household (hectares) \\
\hline Rice farming size & Total rice farming size (hectares) \\
\hline Off-farm employment & Household member has off-farm employment $(1=$ yes; $0=$ no $)$ \\
\hline Number of cattle & Number of cattle owned by household \\
\hline Diversity of rice varieties & Number of rice varieties household cultivates in agricultural year \\
\hline Network with agricultural experts & Number of agricultural experts household head knows \\
\hline Network with customers & Number of rice customers (clients) household head has \\
\hline Membership in economic group & $\begin{array}{l}\text { Household participates in economic group (other than RPCEs) } \\
(1=\text { yes; } 0=\text { no })\end{array}$ \\
\hline Extension service & $\begin{array}{l}\text { Household has been visited for demonstration plot/home by agents, } \\
\text { or has participated in farmer training }(1=\text { yes; } 0=\text { no })\end{array}$ \\
\hline Access to credit & Household has access to credit $(1=$ yes; $0=$ no $)$ \\
\hline Distance to market & Distance to nearest market (mill) in $\mathrm{km}$ \\
\hline Trust & $\begin{array}{l}\text { Household trust in RPCEs' implementation }(0=\text { none; } 1=\text { low; } \\
2=\text { moderate; } 3=\text { high })\end{array}$ \\
\hline
\end{tabular}

\section{Results}

\subsection{Socio-Economic Characteristics of the Respondents}

As shown in Table 2, the demographic characteristics, i.e., age and education level, were similar and insignificantly different. The mean age of members and non-members was 57 years, and most farmers in both groups were educated to primary level. Farmers in the member group who had attained a bachelor's degree or above were more numerous than those in the non-member group, at $30.34 \%$ and $26.32 \%$ respectively. Farm experience was significantly different between members and non-members. Members had more rice farming experience (30 years) than non-members (27 years).

Table 2. Descriptive statistics of sample households by CE membership status.

\begin{tabular}{|c|c|c|c|c|c|}
\hline \multirow{2}{*}{ Variables } & \multicolumn{2}{|c|}{ Members $(N=178)$} & \multicolumn{2}{|c|}{ Non-Members $(\mathrm{N}=228)$} & \multirow[t]{2}{*}{$p$-Value } \\
\hline & Mean & Std. Dev & Mean & Std. Dev. & \\
\hline Age (years) & 57.42 & 12.36 & 57.24 & 11.57 & $0.877^{1)}$ \\
\hline Education level (\%) & & & & & $0.485^{2)}$ \\
\hline Illiteracy & \multicolumn{2}{|c|}{$26.97 \%$} & \multicolumn{2}{|c|}{$31.58 \%$} & \\
\hline Primary school & \multicolumn{2}{|c|}{$38.76 \%$} & \multicolumn{2}{|c|}{$35.96 \%$} & \\
\hline Secondary school & \multicolumn{2}{|c|}{$3.93 \%$} & \multicolumn{2}{|c|}{$6.14 \%$} & \\
\hline Bachelor's degree and above & \multicolumn{2}{|c|}{$30.34 \%$} & \multicolumn{2}{|c|}{$26.32 \%$} & \\
\hline Rice farm experience (years) & 29.94 & 16.30 & 27.19 & 14.0 & $0.069 * 1)$ \\
\hline Landholding size (hectares) & 2.30 & 2.18 & 2.73 & 2.64 & $0.079 * 1)$ \\
\hline Rice farm size (hectares) & 3.43 & 2.89 & 2.92 & 1.87 & $0.030 * 1)$ \\
\hline Rice income (baht) & 111,727 & $85,139.27$ & 102,537 & $68,699.08$ & $0.229^{1)}$ \\
\hline Total income (baht) & 209,671 & $126,994.2$ & 193,591 & $99,870.98$ & $0.154^{1)}$ \\
\hline
\end{tabular}

Note: ${ }^{1)}$ Independent sample t-test of proportions; ${ }^{2}$ Chi-square test; ${ }^{* * *},{ }^{* *}$, and ${ }^{*}$ denote $99 \%, 95 \%$, and $90 \%$ confidence levels, respectively. 
Regarding the economic variables, there was a slight difference in the average size of landholding between members and non-members. Members had a smaller landholding size at 2.30 ha, while non-members averaged $2.73 \mathrm{ha}$. Adversely, the average rice farming land for members was larger (3.43 ha) than for non-members ( $2.92 \mathrm{ha}$ ). There was no significant difference in rice income and total income, but members had a slightly higher rice income (THB 111,727) and total income (THB 209,671) than non-members (THB 102,537 and 193,591 respectively).

\subsection{Farmers' Perception of RPCEs' Roles}

Table 3 shows the farmers' perceptions of RPCEs. Overall, farmers perceived RPCEs' role as a saving source as strong and top among all. Supplying farm inputs at fair price, knowledge and skill improvement, increasing social network, and increasing income were rated as medium. Finally, product competition with rivals and provision of credit service were rated as weak.

Table 3. Farmers' perception regarding RPCEs' roles.

\begin{tabular}{|c|c|c|c|c|c|c|}
\hline \multirow{3}{*}{ Perception } & \multirow{2}{*}{\multicolumn{2}{|c|}{$\begin{array}{l}\text { Members } \\
(n=178)\end{array}$}} & \multirow{2}{*}{\multicolumn{2}{|c|}{$\begin{array}{c}\text { Non-Members } \\
(n=228)\end{array}$}} & \multirow{2}{*}{\multicolumn{2}{|c|}{$\begin{array}{c}\text { Total } \\
(n=406)\end{array}$}} \\
\hline & & & & & & \\
\hline & WAI & I & WAI & $\mathbf{I}$ & WAI & I \\
\hline Saving source & 0.66 & $\mathrm{~S}$ & 0.64 & $S$ & 0.65 & $\mathrm{~S}$ \\
\hline Supplying farm inputs at fair price & 0.67 & $\mathrm{~S}$ & 0.49 & M & 0.57 & $\mathrm{M}$ \\
\hline Knowledge and skill improvement & 0.65 & $\mathrm{~S}$ & 0.48 & M & 0.55 & M \\
\hline Increasing social network & 0.58 & M & 0.49 & M & 0.53 & M \\
\hline Increasing income & 0.50 & M & 0.36 & W & 0.42 & M \\
\hline Product competition with rivals & 0.47 & M & 0.33 & W & 0.39 & W \\
\hline Provision of credit service & 0.33 & $\mathrm{~W}$ & 0.11 & VW & 0.21 & W \\
\hline
\end{tabular}

(I) Interpretation: (VS) Very strong, (S) Strong, (M) Medium, (W) Weak, (SW) Very weak.

Comparing the two groups, it was found that, for both members and non-members, role as a saving source was rated as strong, while increasing social network was rated as medium. Members rated supplying farm inputs at fair price and knowledge and skill improvement as strong, while non-members rated them as medium. Increasing income and product competition with rivals were perceived as medium by members, and weak by non-members. Provision of credit service was considered as weak by members, and very weak by non-members.

\subsection{Factors Affecting Farmers' Perception Level}

Based on the results in Model 1 (Table 4), the perception level of farmers is related to demographic, socio-economic, and infrastructure variables. Age and education influence positive perception of RPCEs. Farmers who grow a diversity of rice varieties have a $15 \%$ increase in positive perception of RPCEs. Moderate and high levels of trust also increase positive perception by $19 \%$ and $53 \%$ respectively. Meanwhile, family size has a negative significant effect on perception level, by about $3.6 \%$. 
Table 4. Determinants of perception and decision to join rice production CEs for paddy farmers $(\mathrm{n}=406)$

\begin{tabular}{|c|c|c|c|c|c|c|}
\hline \multirow{2}{*}{ Description } & \multicolumn{2}{|c|}{ Model 1: Perception } & \multicolumn{2}{|c|}{ Model 2: Decision to Join } & \multicolumn{2}{|c|}{ Marginal Effect } \\
\hline & Coef. & Std. Err. & Coef. & Std. Err. & Perception & Decision to Join \\
\hline Constant & -1.869 & 0.777 & -1.106 & 0.763 & & \\
\hline Age & 0.025 * & 0.013 & -0.001 & 0.014 & 0.005 & -0.000 \\
\hline Education & $0.209 * *$ & 0.106 & 0.067 & 0.103 & 0.046 & 0.017 \\
\hline Family size & $-0.170 *$ & 0.093 & $-0.172 *$ & 0.096 & -0.036 & -0.043 \\
\hline Farm experience & -0.001 & 0.011 & 0.018 * & 0.011 & -0.000 & 0.005 \\
\hline Rice farm size & 0.009 & 0.057 & 0.104 * & 0.061 & 0.002 & 0.026 \\
\hline Landholding & -0.45 & 0.051 & $-0.160^{* * *}$ & 0.057 & -0.010 & -0.040 \\
\hline Off-farm employment & 0.182 & 0.355 & 0.360 & 0.362 & 0.040 & 0.090 \\
\hline Diversity of rice varieties cultivated & $0.677^{* *}$ & 0.282 & $1.045^{* * *}$ & 0.233 & 0.147 & 0.261 \\
\hline Number of cattle & -0.062 & 0.048 & 0.031 & 0.046 & -0.014 & 0.008 \\
\hline Network with agricultural experts & 0.073 & 0.070 & $0.176^{* * *}$ & 0.066 & 0.016 & 0.044 \\
\hline Network with customers & 0.142 & 0.152 & $0.720 * * *$ & 0.260 & 0.031 & 0.180 \\
\hline Membership in economic group & 0.290 & 0.296 & $0.734^{* * *}$ & 0.283 & 0.063 & 0.183 \\
\hline Extension service & 0.139 & 0.276 & $0.613^{* *}$ & 0.268 & 0.030 & 0.153 \\
\hline Access to credit & -0.131 & 0.430 & $0.849^{* *}$ & 0.417 & -0.028 & 0.212 \\
\hline Distance to market & -0.011 & 0.013 & $-0.037^{* *}$ & 0.014 & -0.002 & -0.009 \\
\hline \multicolumn{7}{|l|}{ Trust (none) } \\
\hline Low & -0.396 & 0.430 & & & -0.092 & \\
\hline Moderate & $0.771 * *$ & 0.314 & & & 0.190 & \\
\hline High & $3.057^{* * *}$ & 0.500 & \multirow{2}{*}{\multicolumn{2}{|c|}{136.24}} & 0.526 & \\
\hline $\operatorname{LR} X^{2}$ & 133.36 & & & & & \\
\hline Pseudo $R^{2}$ & 0.2428 & & \multicolumn{2}{|c|}{0.2447} & & \\
\hline Log likelihoods & -207.955 & & \multicolumn{2}{|c|}{-210.210} & & \\
\hline
\end{tabular}

Note: ${ }^{* * *},{ }^{* *}$, and ${ }^{*}$ denote $99 \%, 95 \%$, and $90 \%$ confidence levels, respectively. 


\subsection{Factors' Influencing Farmers' Membership in RPCEs}

In Model 2 (Table 4), the results show that the probability of being a member of an RPCE significantly increases with rice farming experience and rice farm size. Farmers who have cultivated a diversity of rice varieties are more likely to participate in RPCEs, with an approximate $26 \%$ probability of participation. Additionally, social networking with agricultural experts and customers is a significant factor in a farmer's decision to join an RPCE. Networking with agricultural experts and customers increases the probability of RPCE membership by $4 \%$ and $18 \%$ respectively. Membership of an economic group and access to extension service increases the likelihood of RPCE membership by $18 \%$ and $15 \%$ respectively. Furthermore, farmers who can access credit tend to participate in RPCEs. Conversely, family size and landholdings are negatively associated with membership. For farmers with smaller landholdings, every unit fewer of land results in a $4 \%$ higher probability of participation in RPCEs. Distance to market has a significantly negative effect, with each kilometer further away from the market decreasing the likelihood of membership by $1 \%$.

\section{Discussion}

\subsection{Farmers' Perception of RPCEs' Role}

Members and non-members agreed that RPCEs play a vital role as a source of savings. This is consistent with a previous study in Tanzania, which showed that farmer groups promoted saving behavior among members [63]. Members contribute shares, which they will regain if they resign from the group. Furthermore, some RPCEs contribute dividends and provide a deposit account for members.

RPCEs provide inputs to members in the forms of credit and coordination. Due to group purchasing, farmers gain market power and receive better prices for agricultural inputs and other necessities [64]. Regarding credit, the input costs are deducted from the output payment for organic farming members selling their outputs to RPCEs, while other cases use cash payment. In terms of coordination, RPCEs faced with a shortage of capital coordinate partners to buy inputs for their members, and members pay them directly. In fact, RPCEs have a small number of members, which hinders the economies of scale for procurement of inputs. RPCEs achieving a lower input price are not only able to serve low prices to their members, but also to make a profit for the group through charging interest, e.g., $0.5 \%$ per month, or $3 \%$ for the total input cost.

Members and non-members perceived RPCEs' role as being capacity builders, and this perception was particularly strong among members. Government agencies, and non-profit organizations provided various services, such as knowledge transfer and trainings to members in farmer groups in Thailand [65]. This result is consistent with previous studies in Bhutan, and Canada showing that farmer groups act as a knowledge platform and provide access to information and trainings for their members [66,67].

Members and non-members perceived the role of RPCEs as network builders as medium. In the study area, agricultural groups, e.g., RPCEs, cooperatives, and farmer groups, built social networks in the province for reducing transaction costs, facilitating knowledge transfer, enabling the flow of information, and exchanging resources. Research from other regions in Thailand has shown that the RPCE in Uttaraditch province created a network with external bodies [68]. RPCEs with small numbers of members benefit from this network for scale economies achieved in product aggregation through pooling their input procurement with the network. In our study area, some RPCE leaders developed networks with neighboring provinces, e.g., Pitsanulok and Kampheangphet, which benefits all RPCE members. Networking with customers benefits mostly organic farming members and those producing rice for niche markets. Some organic farming members had local customers and contacted them directly at the farm gate. Moreover, RPCEs supported these members in finding customers while waiting for premium market price.

There was a difference in perception regarding the role of RPCEs as income generation enablers, with members perceiving this role more positively. In fact, low input prices can increase the income of all members, but purchasing members' produce at a high price can only increase the income of farmers 
who cultivate organic rice and rice for niche markets. In 2018, RPCEs bought the organic Khao Dok Mali 105 for $15 \mathrm{baht} / \mathrm{kg}$ while mills purchased it at 10-12 baht $/ \mathrm{kg}$. However, some households are reluctant to shift to organic farming because of an unsecure market for this type of rice, which drops yield during the transitional period and uses insufficient household labor [69].

The perception of competition with rivals was also different between the two groups. Agricultural products are competitive when they provide good value for money, quality, and safety in accordance with consumer demand [70]. Production innovation can contribute to organic business development [71]. Some RPCE members prefer cultivating organic rice because of its perceived high quality. Organic rice of RPCEs perceived the Organic Thailand Certification and 5-star OTOP product award. They also favor specific rice varieties, such as Red Jasmine rice, Sinlek rice, and Rice Berry, which are most popular varieties among the health cautious consumers. Furthermore, members prioritize more modern packaging, which can be used not only for household consumption but also for gifts. Meanwhile, non-members perceived that organic rice and rice for the niche market consumption constituted a temporary trend, which is consistent with the prior studies, which showed that farmers had a negative perception of organic farming [69].

Neither members nor non-members perceived RPCEs as providers of credit service, which is linked to the low capacity of RPCEs to lend credit. As pointed out by the study in China, agricultural cooperatives provide very little help with respect to credit facilities for their members [72]. However, when interviewed, some leaders and committees stated that the provision of credits by RPCEs is not necessary and will increase debt to farmers instead of helping them, and that there are already other sources of micro-credit from government programs and commercial banks.

Finally, our findings show that socio-economic factors such as age and education, as well as trust, are the main factors associated with positive perception of RPCEs. The findings suggest that age, education, small size of family, diversity of rice variety cultivated, and trust—in particular moderate and high trust-in RPCEs are significant factors that influence paddy farmers to have a more positive perception of RPCEs.

Individuals' perception and demographic characteristics can be factors of behavioral intention and decision-making $[73,74]$. Analyzing such characteristics may provide a vehicle for understanding the decision-making process of the people being studied and their resultant production methods. In the findings, older and more highly educated farmers were likely to have a more positive perception of RPCEs. This is consistent with a previous study that showed that older and highly educated farmers were more likely to have a positive perception of soil $[75,76]$. It can be implied that older and highly educated farmers know more about RPCEs and are more willing to accept new production and marketing styles. Trust is the feeling that one is not being exploited by others [77], and has been found to be crucial in a farmer group context covering members and directors $[78,79]$. The study found that farmers who have high or moderate trust have a positive perception on RPCEs. Farmers' positive perceptions are of high importance for development of cooperatives $[78,80]$.

\subsection{Factors Influencing Farmers' Membership in RPCEs}

The results of the quantitative analysis showed that landholding, diversity of rice varieties cultivated, networking with agriculture experts and customers, membership in economic groups, extension service, access to credit, and distance to market were the most significant factors influencing membership in RPCEs.

Land is a basic resource for smallholder farmers. The likelihood of cooperative membership increased among landholders with intermediate levels of assets, called the middle-class effect [54]. However, this effect could be explained by the conditions under which collective action can be effective for landholders [49]. Several studies found a relationship between membership and larger landholdings $[3,42,81]$, but this study showed a negative association. Small farmers are more likely to be RPCE members, which could imply that RPCEs are of benefit to poor farmers; this is in line with 
previous studies in Ethiopia and Costa Rica showing that farmers with small landholdings are likely to join cooperatives $[49,61]$.

The probability of RPCE membership increases with the number of rice varieties cultivated. RPCE membership enables farmers to acquire market information on new products in the market. Members are encouraged to cultivate diversity of rice varieties, e.g., rice berries, red brown jasmine rice, and rice for niche markets, in order to offer product varieties to consumers. Similarly to the previous finding, agro-commodity diversification increases the propensity of farmers to join a cooperative [55].

Social networking effects are important for individual decisions, and in the particular context of agricultural innovations, sharing information [82]. In this study, being part of a social network with agricultural experts and customers had a positive and significant effect on RPCE membership. This is consistent with previous research in Ethiopia, where social networks increased the probability of membership in a coffee cooperative [3].

Membership in economic groups (other than rice production RPCEs) also increases the probability of RPCE membership. In economic groups such as food processing and occupational promotion groups, members participate in regular meetings, share their experiences in cultivation and new crop varieties, discuss problems, explore new opportunities for farming and livelihoods, make decisions, plan, and implement other community development programs. This is in agreement with the findings of other studies, which affirmed a positive correlation between group membership and technological uptake $[83,84]$.

Access to extension service is positively associated with probability of membership. Agricultural extension officers are likely to inform and discuss with farmers about the advantages of RPCEs and to affect farmers' decision about membership of an RPCE, a finding that is consistent with the results reported by previous studies that showed that farmers with access to agricultural extension services were likely to be cooperative members $[56,60]$.

Access to credit is very important to small farmers as it helps to diversify their economic base. The more farmers have access to sources of finance, the more likely they are to join RPCEs. Consistently, increase of membership depends on access to credit by farmers in Kenya and Ghana [42,50]. Access to credit services is the main source of finance for medium and lower income households for agricultural production. Farmers are financially empowered if they have access to credit or loans, which help them to adopt modern agricultural technologies [85].

Finally, distance to market was found to be negatively associated with the probability of RPCE membership. Similar findings have been reported for membership of cooperatives in Ethiopia [55], India [62], and Kenya [86]. Farmers located very near to the market are likely to be RPCE members. Farmers in remote areas may prefer selling to traders at lower prices at the farm gate rather than being members of farmer groups.

\section{Conclusions and Recommendations}

CEs is a form of collective action that employs entrepreneurial activities, local resources, social structures, and networks for improving local people' livelihoods. For almost two decades, the Royal Thai Government has promoted CEs and allocated more resources to support grassroots in joining CEs. The RPCE subgroup constitutes the highest registered number of CEs, but few studies have examined farmers' perception or the factors influencing their perception of and decision to join RPCEs. This study has attempted to establish empirical evidence for the perception of farmers on RPCEs' roles and determinants of farmers' perception and decision to join RPCEs by using survey data from households in Uthai Thani province.

The results show that the socio-economic characteristics of the two groups are similar. However, members had more experience and larger rice farm sizes, while non-members had larger landholdings. Regarding farmers' perception of RPCEs' role, on the whole the perception of the two groups was different. Members and non-members strongly agreed that RPCEs constituted a saving source, but they did not perceive them as a credit provider. There was a disparity in perceptions between the two 
groups on supplying farm inputs, knowledge and skill improvement, increasing income, and product competition with rivals. The most significant determinants of farmers' positive perception level were education, diversity of rice varieties cultivated, and high and moderate trust. Furthermore, the most significant factors influencing farmers' decision to join RPCEs were found to be small landholdings, diversity of rice varieties cultivated, networking with agricultural experts and customers, membership in economic groups, extension service, access to credit, and close proximity to market.

Member participation is key to the survival of RPCEs, and securing more benefits for members could in turn improve participation and guarantee sustainable RPCE development. The government should intensify support for RPCEs in order to improve their economic activities in a way that would ensure benefits to members, in particular credit service and supply of members' produce to RPCEs to create income for the group. The negative perception and unsecure market for organic rice and rice for niche markets are the main obstacles blocking farmers from supplying to RPCE groups. The government policy should be production-oriented and make use of participatory training courses, farm visits, on-farm trials to encourage farmers to adopt organic farming, and marketing-oriented endeavors, e.g., price guarantees, standard certification, and promotion of consumption of this rice at both local and country level. Furthermore, government agencies should promote RPCE membership to farmers who have small landholdings, cultivate a diversity of rice varieties, network with agricultural experts and customers, are members of economic groups, have access to extension and credit services, and live near the market. These farmers can access more information and gain more benefits from RPCEs than those with the opposite attributes.

Author Contributions: W.P., S.S., K.K. and V.Y. designed the research. W.P. collected and analyzed the data and drafted the manuscript. S.S. worked on the flow, organizational structure, discussions, conclusions, and review of the manuscript, revising the manuscript and correspondence. K.K. and V.Y. contributed to improving the clarity of the research and review and revising the manuscript.

Funding: This research was funded by the Government of Thailand Ministry of Agriculture and Cooperatives, supporting a scholarship for the first author.

Acknowledgments: The authors gratefully acknowledge the Government of Thailand, Ministry of Agriculture and Cooperatives for supporting a scholarship for the first author. The authors also acknowledge the cooperation from paddy farmers, the leaders and committee of RPCEs, the village head and District Agricultural Extension Officers, and other government authorities in the study area during the data collection. Despite their busy working schedules, the officials and farmer respondents freely offered their cooperation during the interviews and field surveys, which was highly appreciated. We also thank Cooke for proofreading this manuscript.

Conflicts of Interest: The authors declare that there are no conflicts of interest regarding the publication of this article.

\section{References}

1. Oruonye, E.; Musa, Y. Challenges of small scale farmers access to micro credit (Bada kaka) in Gassol LGA, Taraba State, Nigeria. J. Agric. Econ. Dev. 2012, 1, 62-68.

2. Andersen, P.; Shimokawa, S. Rural infrastructure and agricultural development. Paper presented at the Annual Bank Conference on Development Economics, Tokyo, Japan, 29-30 May 2006.

3. Mojo, D.; Fischer, C.; Degefa, T. The determinants and economic impacts of membership in coffee farmer cooperatives: Recent evidence from rural Ethiopia. Rural Stud. 2017, 50, 84-94. [CrossRef]

4. Pingali, P.; Khwaja, Y.; Meijer, M. Commercializing Small Farms: Reducing Transaction Costs; Agricultural and Development Economics Division of the Food and Agriculture Organization of the United Nations: Washington, DC, USA, 2005; pp. 5-8.

5. Narrod, C.; Roy, D.; Okkello, J.; Avendaño, B.; Rich, K.; Thorat, A. Public-private partnership and collection action in high value fruit and vegetable supply chains. Food Policy 2009, 34, 8-15. [CrossRef]

6. Meinzen-Dick, R.; Digregorio, M.; McCarthy, N. Methods for studying collective action in rural development. Agric. Syst. 2004, 82, 197-214. [CrossRef]

7. Vermillion, D. Property rights and collective action in the devolution of irrigation system management. Paper presented at Workshop on Collective Action, Property Rights, and Devolution of Natural Resources, Puerto Azul, Philippines, 21-24 June 2001. 
8. Peredo, A.M.; Chrisman, J. Toward a theory of community-based enterprise. Acad. Manag. Rev. 2006, 31, 309-328. [CrossRef]

9. Torri, M.C. Community entrepreneurship among lower castes in India: A grassroots contribution toward poverty alleviation and rural development under conditions of adversity and environmental uncertainty. Dev. Entrep. 2009, 14, 413-432. [CrossRef]

10. Hayton, K. A critical examination of the role of community business in urban regeneration. Town Plan Rev. 1996, 67, 1-20. [CrossRef]

11. Berkes, F.; Davidson-Hunt, I.J. Innovating through commons: Community-based enterprise. Int. J. Commons 2010, 4, 1-7. [CrossRef]

12. Dhahri, S.; Omri, A. Entrepreneurship contribution to the three pillars of sustainable development: What does the evidence really say? World Dev. 2018, 106, 64-77. [CrossRef]

13. Hall, J.K.; Daneke, G.A.; Lenox, M.J. Sustainable development and entrepreneurship: Past contributions and future directions. J. Bus. Ventur. 2010, 25, 439-448. [CrossRef]

14. Senge, P.; Lichtenstein, B.; Kaeufer, K.; Bradbury, H.; Carroll, J. Collaborating for systemic change. MIT Sloan Manag. Rev. 2007, 48, 44-53.

15. Wheeler, D.; McKague, K.; Thomson, J.; Davies, R.; Medalye, M.; Prada, M. Creating sustainable local enterprise networks. MIT Sloan Manag. Rev. 2005, 47, 33-40.

16. Patzelt, H.; Shepherd, D.A. Recognizing opportunities for sustainable development. Entrep. Theory Pract. 2011, 35, 631-652. [CrossRef]

17. Somerville, P.; McElwee, G. Situating community enterprise: A theoretical exploration. Entrep. Reg. Dev. 2011, 23, 317-330. [CrossRef]

18. Soviana, S. Cooperative, social enterprise, and community-based enterprise: Competing, substituting, or complementing? Manag. Organ. Stud. 2015, 2, 1-14. [CrossRef]

19. Torri, M. Community_based enterprises: A promising basis towards an alternative entrepreneurial model for sustainability enhancing livelihoods and promoting socio-economic development in rural India. J. Small Bus. Entrep. 2012, 23, 237-248. [CrossRef]

20. Teerakul, N.; Villano, R.A.; Wood, F.Q.; Mounter, S.W. A framework for assessing the impacts of community-based enterprises on household poverty. J. Enterp. Communities People Places Glob. Econ. 2012, 6, 5-27. [CrossRef]

21. Valeepitakdej, V.; Wongsurawat, W. Can top-down community enterprise development reduce poverty and out-migration? Evidence from Thailand. Dev. Pract. 2015, 25, 737-746. [CrossRef]

22. Pongpit, S. Community Enterprise is not Community Business in Community Enterprises: Economic Mechanism for Grass Root, 6th ed.; Edison Press Production: Bangkok, Thailand, 2013; pp. 205-219.

23. The Report of the Registered Community Enterprises in Thailand of SCEB. Available online: http://smce. doae.go.th/ProductCategory/smce_report.php (accessed on 7 May 2019).

24. OAE. Annual Report: Agricultural Information in 2013; Report; The Agricultural Cooperative Federation of Thailand: Nonthaburi, Thailand, 2014.

25. Farmers Cultivated Cash Crops in 2014 of DoAE. Available online: http://www.agriinfo.doae.go.th/year57/ general/population/crfs57.pdf (accessed on 12 July 2018).

26. Rakkarn, S.; Ratanamaneichat, C.; Suwandee, S.; Nakrungrueng, W. A model of Thai agricultural co-operative product development and marketing for niche markets. Kasem Bundit J. 2017, 1, 1-10.

27. Khodphue, S.; Sreshthaputra, S. Management competencies of community enterprises in San Pa Tong district, Chiang Mai province, Thailand. In Proceedings of the International Conference on Land Reform for Wealthy Life, Chiang Rai, Thailand, 12-16 May 2008.

28. Sakolnakorn, T.P.N.; Naipinit, A. Guidelines for the management of community enterprises in the Songkhla Lake Basin of Thailand. Asian Soc. Sci. 2013, 9, 166-173. [CrossRef]

29. Purateera, T.; Khmanarong, S.; Phanarata, A.; Khamanarong, K. Influence factors affecting management of small enterprises in northeast Thailand. Int. Bus. Econ. Res. J. 2009, 8, 41-46. [CrossRef]

30. Agbo, F.U. Farmers' perception of cooperative societies in Enugu state, Nigeria. J. Trop. Agric. Food Environ. Ext. 2009, 8, 169-174. [CrossRef]

31. Msimango, B.; Oladele, O.I. Factors influencing farmers' participation in agricultural cooperatives in Ngaka Modiri Molema District. J. Hum. Ecol. 2013, 44, 113-119. [CrossRef] 
32. Neupane, H.; Adhikari, M.; Rauniyar, P.B. Farmers' perception on role of cooperatives in agriculture practices of major cereal crops in Western Terai of Nepal. J. Ins. Agric. Anim. Sci. 2015, 177-186. [CrossRef]

33. Grisanaputi, W. Management of community enterprises: Learning from Thai silk and Thai cotton weaving groups in KhonKaen Province. J. Humanit. Soc. Sci. 2013, 30, 165-188.

34. Naipinit, A.; Promsaka Na Sakolnakorn, T.; Kroeksakul, P. Strategic management of community enterprises in the upper northeast region of Thailand. J. Enterp. Communities People Places Glob. Econ. 2016, 10, 346-363. [CrossRef]

35. Community Enterprise Laws of SCEB. Available online: www.sceb.doae.go.th/law.htm (accessed on 3 October 2018).

36. Community Enterprise Information of SCEB. Available online: http://smce.doae.go.th/index.php (accessed on 11 June 2019).

37. Natsuda, K.; Igusa, K.; Wiboonpongse, A.; Thoburn, J. One village one product-Rural development strategy in Asia: The case of OTOP in Thailand. Can. J. Dev. Stud. 2012, 33, 369-385. [CrossRef]

38. The Community Enterprise Development and Promotion Projects in 2008 of Secretariat of Community Enterprise Board, DoAE. Available online: http://www.sceb.doae.go.th/DataSCEB/ProjectY2551[260950] /ProjectY\%202551-1present(S).ppt (accessed on 24 September 2019).

39. 15 Programs from Government Agendas of MOAC. Available online: https://www.moac.go.th/dwl-files401291791023 (accessed on 21 September 2018).

40. Sakondhavat, A. Understanding Poverty Dynamics Using a Mixed-Method Study: Evidence from the Rural Village in the Northeast and Central Regions of Thailand. Ph.D. Thesis, University of Sussex, Brighton, UK, September 2013.

41. Uthai Thani Provincial Statistic Office. Available online: http://uthai.nso.go.th/index.php (accessed on 12 July 2018).

42. Fischer, E.; Qaim, M. Linking smallholders to markets: Determinants and impacts of farmer collective action in Kenya. World Dev. 2012, 40, 1255-1268. [CrossRef]

43. Awotide, B.A.; Awoyemi, T.T.; Fashogbon, A. Factors influencing smallholder farmers' participation in cooperative organization in rural Nigeria. J. Econ. Sustain. Dev. 2005, 6, 87-97.

44. Shivakoti, G.P.; Thang, T.N.; Dung, N.T.; Hulse, D.; Sharma, S. Redefining diversity and dynamics of natural resources management in Asia. In Natural Resource Dynamics and Social Ecological Systems in Central Vietnam: Development, Resource Changes and Conservation Issues, 3rd ed.; Shivakoti, G.P., Thang, T.N., Dung, N.T., Hulse, D., Sharma, S., Eds.; Elsevier Science: Oxford, UK, 2016; pp. 3-12.

45. Gunawan, E.; Kuwornu, J.K.M.; Datta, A.; Nguyen, L.T. Farmer's perceptions of the warehouse receipt system in Indonesia. Sustainability 2019, 11, 1690. [CrossRef]

46. Khumsri, M.; Ruddle, K.; Shivakoti, G.P. Rights and conflicts in the management of fisheries in the lower Songkhram River Basin, Northeast Thailand. Environ. Manag. 2009, 43, 557-570. [CrossRef]

47. Cofie, O.; Adeoti, A.; Nkansah-Boadu, F.; Awuah, E. Farmers perception and economic benefits of excreta use in southern Ghana. Resour. Conserv. Recycl. 2010, 55, 161-166. [CrossRef]

48. Hajra, R.; Szabo, T.Z.; Ghosh, T.; Matthews, Z.; Foufoula-Georgiou, E. Unravelling the association between the impact of natural hazards and household poverty: Evidence from the Indian Sundarban delta. Sustain. Sci. 2017, 12, 453-464. [CrossRef]

49. Chagwiza, C.; Muradian, R.; Ruben, R. Cooperative membership and dairy performance among smallholders in Ethiopia. Food Policy 2016, 59, 165-173. [CrossRef]

50. Asante, B.O.; Afari-Sefe, V.; Sarpong, D.B. Determinants of small-scale farmers' decision to join farmer-based organizations in Ghana. Afr. J. Agric. Res. 2011, 6, 2273-2279.

51. Pindyck, R.S.; Rubinfeld, D.L. Econometric Models and Economic Forecasts, 4th ed.; Irwin/McGraw-Hill: Boston, MA, USA, 1998.

52. Soviana, S. Toward a Sustainable Community-based Enterprise: Organizational architecture and performance. Manag. Organ. Stud. 2014, 2, 72-86. [CrossRef]

53. Bernard, T.; Taffesse, A.S.; Gebre-Medhin, E.Z. Impact of cooperatives on smallholders' commercialization behavior: Evidence from Ethiopia. Agric. Econ. 2008, 39, 147-161. [CrossRef]

54. Bernard, T.; Spielman, D.J. Reaching the rural poor through rural producer organizations? A study of agricultural marketing cooperatives in Ethiopia. Food Policy 2009, 34, 60-69. [CrossRef] 
55. Francesconi, G.; Heerink, N. Ethiopian agricultural cooperatives in an era of global commodity exchange: Does organisational form matter? Afr. Econ. 2011, 20, 153-177. [CrossRef]

56. Abebaw, D.; Haile, M.G. The impact of cooperatives on agricultural technology adoption: Empirical evidence from Ethiopia. Food Policy 2013, 38, 82-91. [CrossRef]

57. Mojo, D.; Fischer, C.; Degefa, T. Collective action and Aspirations: The impact of cooperatives on Ethiopian coffee farmers' Aspirations. Ann. Public Coop. Econ. 2016, 87, 217-238. [CrossRef]

58. Gupta, K.; Roy, D. Gains from coordination in Milkfed dairy in Punjab. J. Agribus. Dev. Emerg. Econ. 2012, 2, 92-114. [CrossRef]

59. Promme, P.; Kuwornu, J.K.M.; Jourdain, D.; Shivakoti, G.P.; Soni, P. Factors influencing rubber marketing by smallholder farmers in Thailand. Dev. Pract. 2017, 27, 865-879. [CrossRef]

60. Ma, W.; Abdulai, A. Does cooperative membership improve household welfare? Evidence from apple farmers in China. Food Policy 2016, 58, 94-102. [CrossRef]

61. Wollni, M.; Zeller, M. Do farmers benefit from participating in specialty markets and cooperatives? The case of coffee marketing in Costa Rica. Agric Econ. 2007, 37, 243-248. [CrossRef]

62. Sharma, V.P.; Kumar, K.; Singh, R.V. Determinants of Small-Scale Farmer Inclusion in Emerging Modern Agrifood Markets: A Study of the Dairy Industry in India; Working Paper No. 2009-02-01; Indian Institute of Management Ahmedabad: Ahmedabad, India, 2009.

63. Mwaseba, D.L.; Mattee, A.Z.; Kaarhus, R.; Lazaro, E.A.; Mvena, Z.S.K.; Wambura, R.M.; Kiranga, E.D. Perceptions and practices of farmer empowerment in Tanzania. Dev. Pract. 2009, 19, 403-413. [CrossRef]

64. Mohammed, N.; Lee, B.W. Role of cooperatives in rural development, the case of south nations nationalities and people region, Ethiopia. Sci. J. Bus. Manag. 2014, 3, 32-39. [CrossRef]

65. Kwankam, D.; Thechatakerng, P. Production process and management of Thai farmers in community enterprise for organic farming: Some changing. Int. Proc. Econ. Dev. Res. 2011, 13, 1-5.

66. Tenzin, G.; Natsuda, K. Social capital, household income, and community development in Bhutan: A case study of a dairy cooperative. Dev. Pract. 2016, 26, 467-480. [CrossRef]

67. Ferguson, J. Generating sustainable livelihoods; the role of co-operatives. In Cooperative as Transformative Agents in Building Sustainable Livelihoods and reducing poverty. In Proceedings of the Harnessing the Co-Operative Advantage to Build a Better World, Addis Ababa, Ethiopia, 4-6 September 2012; Cooperative Branch, International Labour Office (ILO): Geneva, Switzerland, 2012.

68. Thuansri, Y.; Morathop, N. The network development of organic rice farmers in Uttaradit province: Case study of Wangapee sub-district, Mueng district, Uttaradit province. Lampang Rajabhat Univ. J. 2010, 5, 116-132.

69. Pattanapant, A.; Shivakoti, G.P. Opportunities and constraints of organic agriculture in Chiang Mai province, Thailand. Asia Pac. Dev. J. 2009, 16, 115-147. [CrossRef]

70. Suharyati, A.; Hartono, S.; Waluyati, L.R. Competitive and comparative advantages analysis of organic rice farming in Karanganyar Regency, Central Java province. Ilmu Pertan. 2016, 1, 25-30. [CrossRef]

71. Johne, A. Successful market innovation. Eur. J. Innov. Manag. 1999, 1, 6-11. [CrossRef]

72. Deng, H.; Huang, J.; Xu, Z.; Rozelle, S. Policy support and emerging farmer professional cooperatives in rural China. China Econ. Rev. 2010, 21, 495-507. [CrossRef]

73. Zeweld, W.; Van Huylenbroeck, G.; Tesfay, G.; Speelman, S. Smallholder farmers' behavioural intentions towards sustainable agricultural practices. J. Environ. Manag. 2017, 187, 71-81. [CrossRef]

74. Merleau-Ponty, M. Phenomenology of Perception; Routledge: Abingdon, UK, 2005; pp. 69-73.

75. Ikponmwoda, I.; Abbyssina, M. Factors affecting smallholder farmers' perception regarding their use of soil convservation practices; evidence from farming at Qamata Irrigation Scheme, South Africa. J. Hum. Ecol. 2017, 5, 82-91.

76. Asafu-Adjave, J. Factors affecting the adoption of soil conservation measures: A case study of Fijian cane farmers. J. Agric. Resour. Econ. 2008, 33, 99-117.

77. James, H.S. The trust paradox: A survey of economic inquiries into the nature of trust and trustworthiness. J. Econ. Behav. Organ. 2001, 47, 291-307. [CrossRef]

78. James, H.S.; Sykuta, M.E. Property right and organizational characteristics of producer-owned firms and organizational trust. Ann. Public Coop. Econ. 2005, 74, 545-580. [CrossRef]

79. James, H.S.; Sykuta, M.E. Farmer trust in producer- and investor-owned firms: Evidence from Missouri corn and soybean producers. Agribusiness 2006, 22, 135-153. [CrossRef] 
80. Cechin, A.; Bijman, J.; Pascucci, S.; Omta, O. Decomposing the member relationship in agricultural cooperatives: Implications for commitment. Agribusiness 2013, 29, 39-61. [CrossRef]

81. Verhofstadt, E.; Maertens, M. Can agricultural cooperatives reduce poverty? Heterogeneous impact of cooperative membership on farmers' welfare in Rwanda. Appl. Econ. Perspect. Policy 2015, 37, 86-106. [CrossRef]

82. Uaiene, R.N.; Arndt, C.; Masters, W.A. Determinants of agricultural technology adoption in Mozambique; Discussion papers No. 67E; Ministry of Planning and Development, Republic of Mozambique: Maputo, Mozambique, 2009.

83. Deji, O. Membership of co-operative societies and adoption behaviour of women farmers: Implication for rural development. J. Soc. Sci. 2005, 10, 145-147.

84. Odoemenem, I.; Obinne, C. Assessing the factors influencing the utilization of improved cereal crop production technologies by small scale farmers in Nigeria. Dev. Stud. Res. 2010, 3, 180-183.

85. Asfae, S.; Shiferaw, B.; Simtowe, F.; Lipper, L. Impact of modern agricultural technologies on smallholder welfare: Evidence from Tanzania and Ethiopia. Food Policy 2012, 37, 283-295. [CrossRef]

86. Ngigi, M.; Delgado, C.; Staal, S.J.; Mbogoh, S. The role of market outlet in determining terms for milk sales by smallholders in Kenya. Paper presented at the Symposium on Expanding Market Participation in the Developing World, Annual Meetings of the American Agricultural Economics Association, Tampa, FL, USA, 31 July-3 August 2000; ILRI: Nairobi, Kenya, 2000.

(C) 2019 by the authors. Licensee MDPI, Basel, Switzerland. This article is an open access article distributed under the terms and conditions of the Creative Commons Attribution (CC BY) license (http://creativecommons.org/licenses/by/4.0/). 